\title{
Byssinosis and serum IgE concentrations in textile workers in an Italian cotton mill
}

\author{
L PETRONIO AND M BOVENZI \\ Istituto di Medicina del Lavoro, University of Trieste, Italy
}

ABSTRACT The relationship between serum concentrations of total IgE and byssinosis and other respiratory symptoms was evaluated in 352 textile workers ( 90 men, 262 women) at a cotton mill in Friuli-Venezia Giulia, Italy. The subjects were aged from 20 to 61 (mean 44) and the mean duration of employment was 20 years. One hundred and eight subjects $(30.7 \%)$ were smokers. Only $2 \%$ had a positive history of atopy. A standardised questionnaire showed chronic bronchitis in 96 textile workers $(27.3 \%)$ and byssinosis in $63(17.9 \%)$. The prevalence of respiratory disorders was the same for men and women but was higher in the carding room than in other work areas. Total serum IgE concentrations (RIST, Phadebas) were analysed after log transformation. The geometric mean was $192.7 \mathrm{IU} / \mathrm{ml}$, with no significant difference between the two sexes. This mean concentration of IgE is much higher than that reported internationally for non-atopic subjects, but similar to values found in the Italian population. The IgE concentrations of the workers in the main departments (carding, spinning, and weaving) showed no significant difference. The geometric means were not different in subsamples stratified according to respiratory diseases (cases of pure and cases of mixed forms of chronic bronchitis and byssinosis). A negative result was obtained when IgE concentrations of 289 subjects without byssinosis $(\overline{\mathbf{x}}=$ $188.4 \mathrm{IU} / \mathrm{ml})$ and 63 with byssinosis $(\overline{\mathrm{x}}=212.6 \mathrm{IU} / \mathrm{ml})$ were compared; there was also no trend when the results were analysed by clinical grade of byssinosis. The same negative pattern occurred when the serum IgE concentrations were examined in patients with byssinosis with different grades of chronic change in $\mathrm{FEV}_{1}$. The results of this study support the hypothesis that there is no relationship between total serum IgE concentrations and byssinosis.

Cotton textile workers may complain both of nonspecific lung disease (chronic bronchitis) and the specific syndrome known as byssinosis. Not all findings are in agreement about the prevalence rates of byssinosis. Thus one can find prevalence rates reported from as low as $0.8 \%,,^{1}$ to as high as $40 \% .^{2-4}$ In Italian surveys, frequencies of $6 \cdot 3 \%,{ }^{5} 24$ $27.7 \%,{ }^{67}$ up to $42.5 \%{ }^{8}$ are reported. A higher prevalence in the first phases of cotton manufacture is, however, undisputed..$^{25-8}$

One of the major problems debated is the causal agent, or agents, of byssinosis. At least three hypotheses have been put forward.

Pharmacological theory-This assumes that the cotton dust has a direct constricting effect on the airways ${ }^{9}$ or an action mediated by histamine releas-

Part of the data considered in this paper were presented at the $\mathbf{4 2}$ Congresso Nazionale della Società Italiana di Medicina del Lavoro e di Igiene Industriale. ${ }^{27}$

Received 25 September 1981

Accepted 18 February 1982 ing agents. ${ }^{1011}$ Other authors propose the intervention of proteolytic enzymes which act also by immune mechanisms. ${ }^{12}$

Endotoxin theory-Pernis et al ${ }^{13}$ suggested that byssinosis may be due to endotoxins present in Gram-negative bacteria normally found on cotton plant bracts. The endotoxins are also responsible for "mill fever."

Immunological theory-The pathogenesis of byssinosis has been attributed to a type III immune mechanism in response to specific antigens in the cotton dusts $\mathrm{s}^{14} 15$ or bacterial or fungal contamination. Others ${ }^{16}{ }^{17}$ have claimed a type I, IgE mediated immunological reaction with the release of pharmacological mediators by mast cells and basophils.

The present study was designed to see whether cotton textile workers have raised concentrations of total serum IgE and if there is an association between IgE concentrations and the severity of byssinosis. There are few reports, and the groups of workers examined are often small. Ainsworth et al 
Table 1 Distribution of cotton textile workers by sex, work area, age, duration of employment, and smoking habits

\begin{tabular}{|c|c|c|c|c|c|c|c|c|}
\hline \multirow[t]{2}{*}{ Group } & \multirow{2}{*}{$\begin{array}{l}\text { No of } \\
\text { workers }\end{array}$} & \multicolumn{3}{|l|}{ Work area } & \multirow{2}{*}{$\begin{array}{l}\text { Age } \\
\text { (years) } \\
(\text { mean } \pm S D)\end{array}$} & \multirow{2}{*}{$\begin{array}{l}\text { Duration of } \\
\text { employment } \\
\text { (years) } \\
\text { (mean } \pm S D)\end{array}$} & \multicolumn{2}{|c|}{ Smoking habits } \\
\hline & & $\begin{array}{l}\text { Carding } \\
\text { No (\%) }\end{array}$ & $\begin{array}{l}\text { Spinning } \\
\text { No (\%) }\end{array}$ & $\begin{array}{l}\text { Weaving } \\
\text { No (\%) }\end{array}$ & & & $\begin{array}{l}\text { All } \\
\text { smokers } \\
(\%)\end{array}$ & $\begin{array}{l}\geqslant 15 \\
\text { cigarettes/day } \\
(\%)\end{array}$ \\
\hline $\begin{array}{l}\text { Total } \\
\text { Men } \\
\text { Women }\end{array}$ & $\begin{array}{r}352 \\
90 \\
262\end{array}$ & $\left.\left.\begin{array}{l}24 \\
14 \\
10\end{array}\right\} \begin{array}{r}6 \cdot 8) \\
15 \cdot 5 \\
3 \cdot 8\end{array}\right)$ & $\begin{aligned} 148 & (42 \cdot 0) \\
27 & (30 \cdot 0) \\
121 & (46 \cdot 1)\end{aligned}$ & $\begin{aligned} 180 & (51 \cdot 1) \\
49 & (54 \cdot 4) \\
131 & (50 \cdot 0)\end{aligned}$ & $\begin{array}{l}43 \cdot 9 \pm 8 \cdot 5 \\
46 \cdot 5 \pm 8 \cdot 3 \\
42.9 \pm 8 \cdot 4\end{array}$ & $\begin{array}{l}20.0 \pm 9.5 \\
20.2 \pm 10.8 \\
20.0 \pm 9.0\end{array}$ & $\begin{array}{l}30.7 \\
53 \cdot 3 \\
22.9\end{array}$ & $\begin{array}{r}11 \cdot 1 \\
30.0 \\
4.6\end{array}$ \\
\hline
\end{tabular}

have reported (at a symposium on cotton dust at Atlanta in 1974) that when studying serum IgE concentrations in 19 mill workers they found that 14 (with no history of allergy) had raised IgE concentrations not related to the severity of byssinosis. We found similar results in the preliminary analysis of the data of a cross-sectional survey in mill workers. ${ }^{18}$ We have examined these data further because the IgE values are not normally distributed and are therefore more correctly analysed after logarithmic $\left(\log _{10}\right)$ transformation.

\section{Materials and methods}

\section{PATIENTS}

In 1978352 textile workers at a cotton mill in Gorizia, Italy, were examined at the Institute of Occupational Health of the University of Trieste. They underwent a series of examinations including a medical history, a physical examination, chest $x$-ray examination, pulmonary function tests, determination of the main haematological and biochemical variables and total serum IgE concentrations. The study was triggered by a claim of the workers' unions.* The mill processes cotton for the whole cycle (from the raw cotton to the finished product) passing through carding process to spinning, up to weaving. The population under study was composed of 90 men and 262 women, aged between 20 and 61 . About $7 \%$ of the workers (24/352) were in the carding area, $42 \%(148 / 352)$ in spinning, and $51 \%$ $(180 / 352)$ in weaving (table 1). Their mean age was 44 , with men slightly older (three years) than women; $65 \%$ of the study population was aged 40 and over. The average period of employment at the cotton mill was 20 years, the same for both sexes. One hundred and eight workers $(30.7 \%)$ smoked; more men smoked than women $(48 / 90$ versus $60 /$ 262) and they smoked more heavily.

* Since 1975 in Italy the scheduled occupational diseases have been extended and cotton dust has been recognised as a hazard to be covered by workers' compensation.

\section{RESPIRATORY DISEASES}

A standardised questionnaire was administered to investigate the frequency of respiratory diseases. The questionnaire satisfied the Medical Research Council criteria for chronic bronchitis, with additional questions on byssinosis. ${ }^{19}$ Pulmonary function was evaluated with a Jaeger Spirotest Junior bellows spirometer. Predicted normal values were taken from Council of European Communities. ${ }^{20}$ The details of the respiratory function tests have been presented elsewhere ${ }^{19}$ and will not be referred to here.

Altogether 223 workers (63.3\%) gave no history of respiratory ailments. Among the other 129 subjects, $30(8.5 \%$ of the entire sample) responded affirmatively to questions on both chronic bronchitis and byssinosis: 96 subjects $(27 \cdot 3 \%)$ gave answers compatible with a diagnosis of chronic bronchitis and $63(17.9 \%)$ with a diagnosis of byssinosis according to Schilling's criteria. ${ }^{19}$ In the carding area the prevalence of respiratory diseases (byssinosis $37.5 \%$, chronic bronchitis $50.0 \%$ ) was significantly higher than in the spinning (byssinosis 15.5\%, chronic bronchitis $26.3 \%$ ) and weaving areas (byssinosis $17.2 \%$, chronic bronchitis $25.0 \%$ ). Of the 63 subjects who reported symptoms of byssinosis, 48 were grade $1 / 2$ or 1 and 15 were graded 2-3 (table 2 ). This distribution was similar in both men and women.

Table 2 Prevalence of clinical grades of byssinosis in textile workers by sex

\begin{tabular}{|c|c|c|c|}
\hline & \multicolumn{3}{|c|}{ Clinical grades of byssinosis* } \\
\hline & $1 / 2$ & 1 & $2+3$ \\
\hline $\begin{array}{l}\text { Total }(n=352) \\
\text { Men }(n=90) \\
\text { Women }(n=262)\end{array}$ & 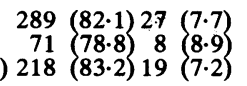 & 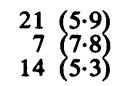 & $\begin{array}{r}15(4 \cdot 2) \\
4(4 \cdot 4) \\
11(4 \cdot 2)\end{array}$ \\
\hline \multicolumn{4}{|c|}{$\begin{array}{l}\text { *Clinical grading according to Roach and Schilling: } 19 \\
\text { Grade 0: No symptoms of byssinosis. } \\
\text { Grade 1/2: Occasional chest tightness or cough, or both, on first } \\
\text { day of the working week. } \\
\text { Grade 1: Chest tightness on every first day of the working week. } \\
\text { Grade 2: Chest tightness on first and other days of the working } \\
\text { week. } \\
\text { Grade 3: Grade } 2 \text { symptoms accompanied by evidence of permanent } \\
\text { incapacity. } \\
\text { Significance (Chi square): Men } v \text { women } \chi^{2}(2 \cdot 4)=1 \cdot 059 \text {, NS. }\end{array}$} \\
\hline
\end{tabular}


Table 3 Chronic changes in FEV in textile workers complaining of pure and mixed forms of byssinosis and chronic bronchitis

\begin{tabular}{|c|c|c|c|}
\hline & $\begin{array}{l}\text { Byssinosis } \\
(n=33)\end{array}$ & $\begin{array}{l}\text { Chronic } \\
\text { bronchitis } \\
(n=66)\end{array}$ & $\begin{array}{l}\text { Byssinosis and } \\
\text { chronic bronchitis } \\
(n=30)\end{array}$ \\
\hline $\begin{aligned}{ }^{*} \text { FEV }_{1} \% & \geqslant 82 \\
\text { FEV } \% & <82\end{aligned}$ & 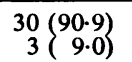 & 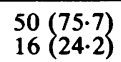 & 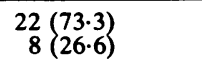 \\
\hline
\end{tabular}

${ }^{*} \mathrm{FEV}_{1}$ observed as percentage of predicted CECA value. ${ }^{20}$

Only a small proportion of those workers with symptoms of byssinosis had a chronic ventilatory impairment, as defined by a FEV $<82 \%$ of the predicted value (table 3 ).

\section{ATOPY}

Only $2 \%$ of the workers had a positive history of atopy. No standardised questionnaire was administered, but the reporting of complaints of hay fever, childhood history of asthma, and atopic dermatitis was considered accurate.

\section{IgE DETERMINATION}

Serum IgE concentrations were determined by the radioimmunosorbent technique (RIST, Phadebas) performed as recommended by Pharmacia Diagnostics AB, Uppsala. The IgE concentration are reported in international units $(\mathrm{IU} / \mathrm{ml})$. $^{*}$

\section{STATISTICAL ANALYSIS}

Statistical analysis was made after logarithmic $\left(\log _{10}\right)$ transformation of the IgE values. In this way a more normal distribution was reached, and the parametric statistical tests could be used. The data analysis was performed using SPSS (statistical package for the social sciences) computer programs. A p value greater than $\mathbf{0 . 0 5}$ was considered not significant.

\section{Results}

The IgE concentration determined in 352 cotton workers has a log-normal distribution with a wide scatter from 10 to $4498 \mathrm{IU} / \mathrm{ml}$. The arithmetical mean was $371.2 \mathrm{IU} / \mathrm{ml}$, the logarithmic mean 2.285 $\mathrm{IU} / \mathrm{ml}(\mathrm{SD} \pm 0.504)$, and the geometric mean 192.7 $\mathrm{IU} / \mathrm{ml}$. We feel that transformation was justified because the original distribution was asymmetrical (skewed to the right) whereas the distribution of the transformed data is more nearly normal (fig 1).

There was no statistically significant difference in the IgE concentrations found in men (mean of $\log _{10}$

${ }^{*} 1 \mathrm{IU} \simeq 2.4$ nanograms

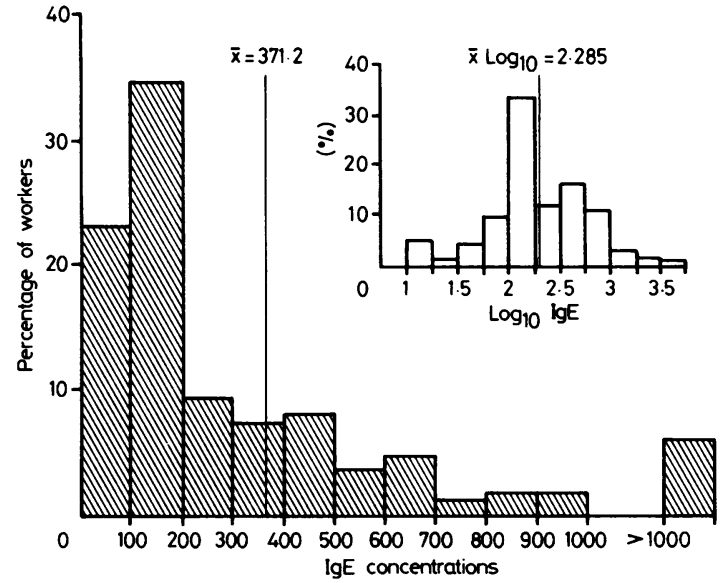

Fig 1 Percentage distribution and mean value $(\bar{x})$ of total serum IgE concentrations (IU/ml) in textile workers expressed in raw numbers and after $\log _{10}$ transformation.

Table 4 Serum IgE concentrations (IU/ml) in relation to work area

\begin{tabular}{lcccl}
\hline Work area & $\begin{array}{l}\text { No of } \\
\text { workers }\end{array}$ & Mean $\log _{10}$ IgE & $S D$ & $\begin{array}{l}\text { Geometric mean } \\
\text { IgE (IU/ml) }\end{array}$ \\
\hline Carding & 24 & 2.318 & 0.712 & 207.9 \\
Spinning & 148 & 2.298 & 0.445 & 198.6 \\
Weaving & 180 & 2.269 & 0.519 & 185.8 \\
\hline
\end{tabular}

Significance (Student's $t$ test): Carding $v$ spinning $t=0.136$, NS; carding $v$ weaving $t=0.327$, NS; spinning $v$ weaving $t=0.54$, NS.

$=2.224, \mathrm{SD} \pm 0.584 ;$ geometric mean $=167.5$ $\mathrm{IU} / \mathrm{ml}$ ) or women (mean of $\log _{10}=2 \cdot 305, \mathrm{SD} \pm$ 0.473 ; geometric mean $=201.9 \mathrm{IU} / \mathrm{ml})$. Student's $t$ value was $1 \cdot 19, \mathrm{p}>0.05$. There was also no significant difference between the IgE concentrations of the workers from the three main areas (carding, spinning, weaving) (table 4).

To evaluate the relationship between IgE concentrations and respiratory diseases, we divided the workers into four subgroups: workers without respiratory ailments (223), workers suffering from chronic bronchitis (66), workers with symptoms of byssinosis (33), and workers complaining of both byssinosis and chronic bronchitis (30). The geometric mean and the standard deviation (SD) were determined for each group but no statistically significant differences were found (fig 2). A negative result was also found when the IgE concentrations of patients complaining of byssinosis and the remainder of the work force were compared (fig 3), and when IgE concentrations were examined according to clinical grading.

Finally, IgE concentrations were compared in workers with byssinosis with and without chronic 


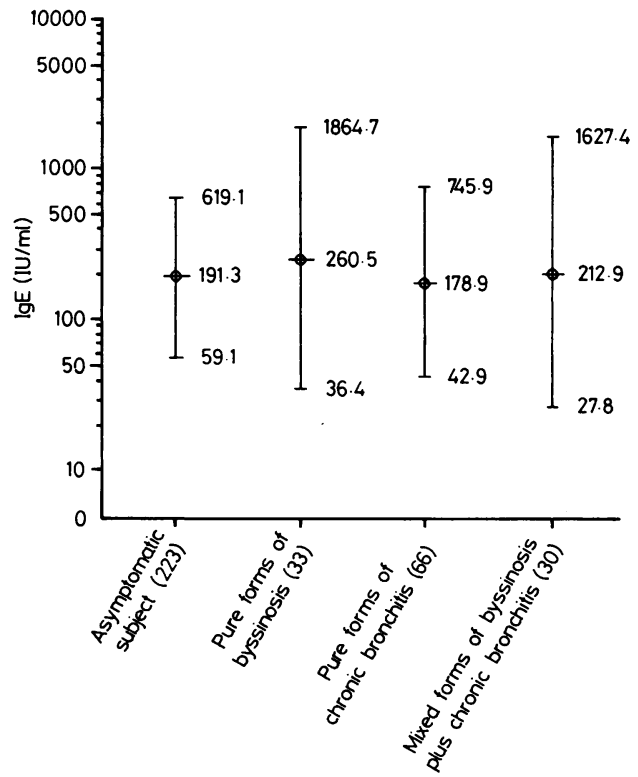

Fig 2 Geometric mean values ( $\pm S D$ ) of total serum IgE in textile workers with or without symptoms of byssinosis or chronic bronchitis or both. Significances (t test): $(A) v(B y)$, $t=0.88, N S ;(A) v(C B), t=0.35, N S ;(A) v(B y+C B)$, $t=0.28, N S ;(B y) v(C B), t=0.97, N S ;(B y) v(B y+C B)$, $t=0.40, N S$; $(C B) v(B y+C B), t=0.42, N S$.

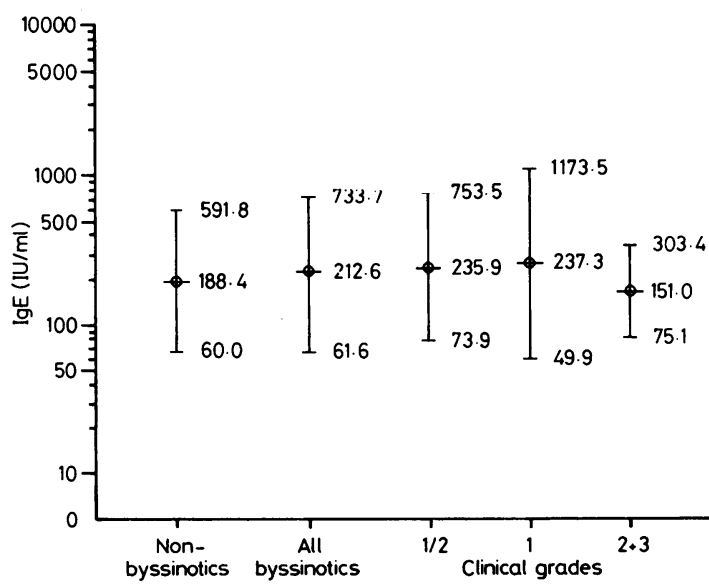

Fig 3 Serum IgE concentrations (geometric mean $\pm S D$ ) in workers with (63) or without (289) byssinosis and in relation to clinical grades of byssinosis: $1 / 2(27), 1(21), 2+$ 3 (15). Significances (t test): all By $v$ non-By, $t=0.75, \mathrm{NS}$; $1 / 2 v 1, t=0.01, N S ; 1 / 2 v 2+3, t=1.35 ; N S ; 1 v 2+3$, $t=1.02, N S$.

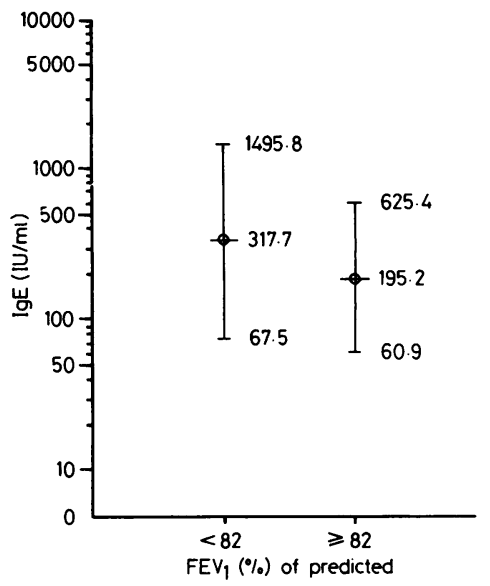

Fig 4 Serum IgE concentrations (geometric mean $\pm S D$ ) in patients with byssinosis with $(F E V,<82 \%, n=11)$ or without $\left(F E V_{1} \geqslant 82 \%, n=52\right)$ ventilatory impairment. Significance ( $t$ test $): t=1 \cdot 18, N S$.

impairment of pulmonary function. Workers with an $\mathrm{FEV}_{1}$ greater than $82 \%$ of the predicted value were considered to have borderline or no chronic ventilatory impairment whereas those with an $\mathrm{FEV}_{1}$ less than $82 \%$ were considered to have moderate to severe impairment. No significant difference in IgE concentrations could be found between the groups (fig 4).

\section{Discussion}

In the group of 352 textile workers the geometric mean serum IgE concentration was $192.7 \mathrm{IU} / \mathrm{ml}$. Our first question was, is such a mean value different from that of the general population? At first sight, a comparison with reported normal values suggests that the answer is yes.

Johansson and Foucard ${ }^{21}$ report that in adults the normal mean concentrations of IgE are between 15 and $100 \mathrm{U} / \mathrm{ml}$, underlining the fact that the variability is dependent on the methodology and selection of the normal subjects. One hundred and two individuals of the United Kingdom aged from 18 to 83, accurately selected by Nye $e t a l^{22}$ with respect to atopy, were found to have a mean total serum IgE concentration of $36 \cdot 3 \mathrm{U} / \mathrm{ml}$ (geometric mean $21 \cdot 2$ ). The method of measurement of IgE was based on a highly sensitive double antibody assay. Burr $e a^{23}$ in an epidemiological survey, once again in the United Kingdom, with the same method of measurement, found a mean value of $31 \mathrm{U} / \mathrm{ml}$. Higher values are reported by American authors, however. In a com- 
munity population sample of Tucson (Arizona) Brown et al ${ }^{24}$ reported that in 148 subjects defined as "non-allergic" with a mean age of 35 , the mean value of total IgE measured with Phadebas PRIST was $107 \mathrm{IU} / \mathrm{ml}$.

When comparing data from different studies, however, it must be remembered that the test techniques for the determination of total serum IgE are very different (radioimmunosorbent test, RIST, double-antibody radioimmunoassay, RIA, paper disc immunosorbent test, PRIST) and that socioeconomic and constitutional factors may differ; Anglo-Saxon and Scandinavian populations may not be the same in respect of these factors as Italians.

More correctly we should have compared the total IgE concentrations of our textile workers with those of a control group. It was not possible for us to perform a survey in the general population but in a recent investigation of total IgE concentrations (PRIST Phadebas) performed in the general population in Rome ${ }^{25}$ the concentrations reported were considerably higher compared with those reported internationally but were not very different from our own. In 134 "apparently healthy" subjects with no family history of allergy, aged between 7 and 94, the mean value of $\operatorname{IgE}$ in the entire sample (male and female) was $138 \cdot 1 \mathrm{U} / \mathrm{ml}$ with standard deviation of $\pm 215 \cdot 5$. In those aged between 40 and 60 the mean IgE concentration was $154.8 \mathrm{U} / \mathrm{ml}$. This age group comprised $65 \%$ of the patients we examined.

Although our sample is biased by a small "contamination" with atopic subjects and our method (RIST) tends to overestimate the low IgE concentrations, ${ }^{22}$ we can feel justified in assuming that total serum IgE concentrations in our textile workers are higher than the values reported internationally but not dissimilar from values reported for other Italian subjects.

When interpretating the raised total serum $\operatorname{IgE}$ found in the Italian samples, an account must be taken of the high frequency of parasitic infestations of minor clinical relevance (and then not recorded in the personal history).

The main purpose of this study, however, was to see if there was a relation between total serum IgE and respiratory diseases, particularly byssinosis, in textile workers.

To do this, we first divided our sample of cotton textile workers into three subgroups according to their working area (carding, spinning, or weaving). The results of the questionnaire on respiratory symptoms (table 2) were agreed with other reports. ${ }^{2-8}$ Both chronic bronchitis and byssinosis had a high prevalence in the workers of the carding area; among 24 carders nine subjects complained of byssinosis and 12 were affected by chronic bron- chitis. The mean concentration of IgE in the carding room workers, however, was not significantly different from that of the workers in the other areas.

Secondly, we considered the concentrations of $\mathrm{IgE}$ in the various forms of respiratory syndrome. The subjects affected only by byssinosis presented higher concentrations of total IgE than healthy workers or those affected only by bronchitis. The total serum IgE had an intermediate concentration in the subjects complaining of both byssinosis and chronic bronchitis; this trend did not reach conventional levels of statistical significance, however.

In two subgroups of the sample, one consisting of all 63 subjects suffering from byssinosis (with or without bronchitis) and the other of all the workers with grade 0 , there was no significant difference in the geometric mean value of total serum IgE. Further analysis of the byssinotic group showed that the different clinical grades $(1 / 2,1,2+3)$ are not associated with significantly different total serum IgE concentrations; the most severe forms the IgE have, on average, the lower value.

In a recent study Jones $e{ }^{a l^{26}}$ reported that atopy and cotton dust exposure have a significant interaction in the acute decline of expiratory flow rates $\left(\mathrm{FEF}_{25-75}\right)$ and in $\mathrm{FEV}_{1}$ over working shifts. They conclude that atopy represents a risk factor in byssinosis. We did not have the opportunity to investigate the acute effect of cotton dust on pulmonary function. Therefore we cannot state if an increased bronchoconstrictive response is associated with raised concentrations of total serum IgE.

Our cotton textile workers were not examined in the mill, thus we can consider only chronic respiratory impairment, and we did not find a significant association between the $\mathrm{IgE}$ concentration of patients with byssinosis and then loss of lung function $\left(\mathrm{FEV}_{1}\right)$.

In conclusion, with all the reservations noted, the statistical analysis of total serum IgE concentrations in different subgroups of textile workers does not give support for an association between total IgE and byssinosis.

We thank Mr F DeGrassi for statistical help.

\section{References}

' Field GB, Owen P. Respiratory function in an Australian cotton mill. Bull Europ Physiopathol Respir 1979;156:455-68.

${ }^{2}$ Molyneux MKB, Tombleson JBL. An epidemiological study of respiratory symptoms in Lancashire mills. $\mathrm{Br} \mathrm{J}$ Ind Med 1970;27:225-34.

${ }^{3}$ Bouhuys A, Wolfson RL, Horner DW, Brain JD, Zuskin E. Byssinosis in cotton textile workers; respiratory survey of a mill with a rapid labor turnover. Ann Intern Med 1969;71:257-69. 
4 Cinkotai FF, Lockwood MG, Rylander R. Airborne microorganisms and prevalence of byssinotic symptoms in cotton mills. Am Ind Hyg Assoc J 1977;38:554-9.

5 Clonfero E, Marcer G, Di Maria O, Minisini P. Effetti acuti e cronici della inalazione della polvere di cotone: uno studio sulla bissinosi. Med Lav 1976;67:427-42.

- Cavagna G. Progressi negli studi sulla patogenesi della bissinosi. Med Lav 1969;60:401-8.

' Foà V, Zedda S, Cardani A, Marzoli C, Peruzzo G, Giobbi A, Vigliani EC. Patologia da fibre tessili vegetali. Med Lav 1975;66:527-72.

- Sassi C, Cavagna G, Finulli M. La bissinosi in un cotonificio della Lombardia. Med Lav 1969;53:673-81.

9 Bouhuys A, Lindell SE, Lundin G. Experimental studies in byssinosis. Br J Ind Med 1960;9:324-6.

${ }^{10}$ Hitchcock M, Piscitelli DM, Bouhuys A. Histamine release from human lung by a component of cotton bracts and by compound 48/80. Arch Environ Health 1973;26:177-82.

" Ainsworth SK, Neuman RE, Harley RA. Histamine release from platelets for assay of byssinogenic substances in cotton mill dust and related materials. Br J Ind Med 1979;35:35-42.

12 Braun DC, Scheel LD, Tuma J, Parker L. Physiological response to enzymes in cotton dust. JOM 1973;15:241-4.

${ }^{13}$ Pernis B, Vigliani EC, Cavagna G, Finulli M. The role of bacterial endotoxins in occupational diseases caused by inhaling vegetable dusts. Br J Ind Med 1961;18:120-9.

${ }^{14}$ Massoud A, Taylor G. Byssinosis: antibody to cotton antigens in normal subjects and in cotton card-room workers. Lancet 1964;ii:607-10.

15 Taylor G, Massoud A, Lucas F. Studies on the aetiology of byssinosis. Br J Ind Med 1971;28:143-51.

${ }^{16}$ Prausnitz C. Investigations on respiratory dust disease in operatives in the cotton industry. London: HMSO, 1936. (Medical Research Council Special Report Series No 212.)

${ }^{17}$ Gernez-Rieux C, Voisin C, Jacob M, Corsin L, Lefebvre J. Enquete allergologique chez $\mathbf{4 0}$ ouvriers de filature de coton souffrant de trouble dyspneiques du travails. Poumon
1962;18:651-9.

18 Petronio L, Bovenzi M, Fiorito A, et al. Patologia respiratoria in un'industria tessile: risultati preliminari. In: Le broncopneumopatie professionali con particolare riferimento a quelle di nuova tabellazione, Milano, Italia, 1978. Roma: Istituto Italiano di Medicina Sociale, 1979:85-100.

19 Roach SA, Schilling RSF. A clinical and environmental study of byssinosis in the Lancashire cotton industry. $\mathrm{Br} J$ Ind Med 1960;17:1-9.

${ }^{20}$ Commission des Communautés Européennes. Aide-mémoire pour le pratique de l'examen de la function ventilatoire par la spirographie. 2nd ed. Luxembourg: CECA, 1971. (Collection d'hygiène ed de médecine du travail No 11.)

21 Johansson SGO, Foucard T. IgE in immunity and disease. In: Middleton E jr, Reed CE, Ellis EF, eds. Allergy: principles and practice. Saint Louis: CV Mosby Company, 1978:551-62.

${ }^{22}$ Nye L, Merrett TG, Landon J, White RJ. A detailed investigation of circulating IgE levels in a normal population. Clin Allergy 1975;1:13-24.

${ }^{23}$ Burr ML, St Leger AS, Bevan C, Merrett TG. A community survey of asthmatic characteristics. Thorax 1975;30:663-8.

24 Brown WG, Halonen MJ, Kaltenborn WT, Barbee RA. The relationship of respiratory allergy, skin test reactivity, and serum IgE in a community population sample. J Allergy Clin Immunol 1979;63:328-35.

${ }^{25}$ Bonini S, Rosa C, Rasi G, Falangiani P, Simoni L, Zaffiro A. IgE sieriche totali e specifiche in soggetti apparentemente sani con e senza familiarità allergica. Folia Allergologica et Immunologica Clinica 1980;27:261-8.

${ }^{26}$ Jones RN, Butcher BT, Hammad YY, et al. Interaction of atopy and exposure to cotton dust in the bronchoconstrictor response. Br J Ind Med 1980;37:141-6.

${ }^{27}$ Societa Italiana di Medicina del Lavoro e di lgiene Industriale. Rischi, malattie professionali e prevenziore nell'industria teosile. In: Atti del $42^{\circ}$ Congresso Nazionale della Societè Italiana di Medicina del Lororo e di lguiene Industriale. Vol 3. Trieste, Italia: Cluet, 1979:1-339. 